Article

\title{
Ground-Level $\mathrm{NO}_{2}$ Concentrations over China Inferred from the Satellite OMI and CMAQ Model Simulations
}

\author{
Jianbin Gu ${ }^{1,2}$, Liangfu Chen ${ }^{1, *}$, Chao Yu ${ }^{1,3, *}$, Shenshen $\mathrm{Li}^{1}{ }^{1}$, Jinhua Tao ${ }^{1}$, Meng Fan ${ }^{1}$, \\ Xiaozhen Xiong ${ }^{4}$, Zifeng Wang ${ }^{1}$, Huazhe Shang ${ }^{1}$ and Lin $\mathrm{Su}^{1}$ \\ 1 State Key Laboratory of Remote Sensing Science, Institute of Remote Sensing and Digital Earth, \\ Chinese Academy of Sciences, Beijing 100101, China; gujianbin110@163.com (J.G.); liss01@radi.ac.cn (S.L.); \\ taojh@radi.ac.cn (J.T.); fanmeng@radi.ac.cn (M.F.); wangzf@radi.ac.cn (Z.W.); huazhe_zhang@126.com (H.S.); \\ sulin@irsa.ac.cn (L.S.) \\ 2 University of the Chinese Academy of Sciences, Beijing 100049, China \\ 3 State Key Joint Laboratory of Environment Simulation and Pollution Control, School of Environment, \\ Tsinghua University, Beijing 100101, China \\ 4 NOAA/NESDIS/Center for Satellite Applications and Research, College Park, MD 20740, USA; \\ xiaozhen.xiong@noaa.gov \\ * $\quad$ Correspondence: chenlf@radi.ac.cn (L.C.); yuchao@radi.ac.cn (C.Y.); Tel.: +86-10-6483-6589 (L.C.) \\ Academic Editors: Yang Liu, Jun Wang, Omar Torres, Richard Müller and Prasad S. Thenkabail \\ Received: 9 March 2017; Accepted: 19 May 2017; Published: 24 May 2017
}

\begin{abstract}
In the past decades, continuous efforts have been made at a national level to reduce Nitrogen Dioxide $\left(\mathrm{NO}_{2}\right)$ emissions in the atmosphere over China. However, public concern and related research mostly deal with tropospheric $\mathrm{NO}_{2}$ columns rather than ground-level $\mathrm{NO}_{2}$ concentrations, but actually ground-level $\mathrm{NO}_{2}$ concentrations are more closely related to anthropogenic emissions, and directly affect human health. This paper presents one method to derive the ground-level $\mathrm{NO}_{2}$ concentrations using the total column of $\mathrm{NO}_{2}$ observed from the Ozone Monitoring Instrument (OMI) and the simulations from the Community Multi-scale Air Quality (CMAQ) model in China. One year's worth of data from 2014 was processed and the results compared with ground-based $\mathrm{NO}_{2}$ measurements from a network of China's National Environmental Monitoring Centre (CNEMC). The standard deviation between ground-level $\mathrm{NO}_{2}$ concentrations over China, the CMAQ simulated measurements and in-situ measurements by CNEMC for January was $21.79 \mu \mathrm{g} / \mathrm{m}^{3}$, which was improved to a standard deviation of $18.90 \mu \mathrm{g} / \mathrm{m}^{3}$ between our method and CNEMC data. Correlation coefficients between the CMAQ simulation and in-situ measurements were 0.75 for January and July, and they were improved to 0.80 and 0.78 , respectively. Our results revealed that the method presented in this paper can be used to better measure ground-level $\mathrm{NO}_{2}$ concentrations over China.
\end{abstract}

Keywords: $\mathrm{NO}_{2}$; ground-level concentrations; OMI; CMAQ; profile shape

\section{Introduction}

Nitrogen dioxide $\left(\mathrm{NO}_{2}\right)$ is a pollutant trace gas in the atmosphere that plays an important role in atmospheric tropospheric chemistry and radiative heating [1-3]. Atmospheric ozone chemistry is affected by $\mathrm{NO}_{2}$ in terms of ozone formation, whereas in the troposphere, $\mathrm{NO}_{2}$ regulates the surface ozone level and maintains oxidizing capacities [4]; furthermore, exposure to ozone leads to adverse health effects for humans [5]. At high concentrations, $\mathrm{NO}_{2}$ is toxic to humans [6,7]. Some epidemiological studies have shown that long-term $\mathrm{NO}_{2}$ exposure is consistently associated with decreased lung function and with increased risks of respiratory symptoms [8-13], and daily time-series research results show that $\mathrm{NO}_{2}$ and non-accidental mortality are strongly correlated [14-16]. 
In addition, $\mathrm{NO}_{2}$ can initiate the formation of acid rain and can indirectly affect the global climate by perturbing greenhouse gas, ozone and methane levels [3]. Furthermore, $\mathrm{NO}_{2}$ is a precursor of ammonium nitrate, which is an important component of atmospheric particulate matter pollution [17].

Concentrations of $\mathrm{NO}_{2}$ columns are traditionally monitored through in-situ measurement networks [18]; however, these in-situ measurements are sparse in many parts of the world. Since 1995, satellite retrievals of $\mathrm{NO}_{2}$ columns have provided more measurements than the ground-based and aircraft measurements. Some attempts to estimate emission levels have been made using a top-down approach [19] and satellite measurements. These studies show that satellite remote sensing can be used to monitor $\mathrm{NO}_{2}$ columns at regional to global scales [20-22]. Satellite observations of global $\mathrm{NO}_{2}$ columns began in 1995 with the development of the Global Ozone Monitoring Experiment (GOME) [23], followed by launch of the Scanning Imaging Absorption Spectrometer for Atmospheric Chartography (SCIAMACHY) [24], the Ozone Monitoring Instrument (OMI) onboard Earth Observing System (EOS)/Aura [25,26], and the GOME-2 [27]. The retrieval of tropospheric $\mathrm{NO}_{2}$ columns is especially relevant to the state of the atmosphere (e.g., $\mathrm{NO}_{2}$ profile shape). The uncertainties of GOME, SCIAMACHY and OMI observations are estimated to be on the order of $30-60 \%$ for individual measurements [28-31].

Over the last decades, the incredible economic growth of China has led to serious atmosphere pollution problems, continuous efforts have been made at national levels to reduce $\mathrm{NO}_{2}$ emissions in the atmosphere. The monitoring of long-term pollutant emissions and the trend of concentration has been a key aspect of the evaluation of $\mathrm{NO}_{2}$ emission abatement strategy effects. However, public concern and related research based on satellite observations of $\mathrm{NO}_{2}$ columns have been focusing mainly on tropospheric $\mathrm{NO}_{2}$ columns instead of ground-level $\mathrm{NO}_{2}$ concentrations; when actually, ground-level $\mathrm{NO}_{2}$ concentrations are more closely linked to the air pollution and impact on human health. This paper presents a method of estimating ground-level $\mathrm{NO}_{2}$ concentrations over China based on tropospheric $\mathrm{NO}_{2}$ columns retrieved from the OMI and model simulations. Section 2 provides a brief introduction to OMI and its retrieval of tropospheric $\mathrm{NO}_{2}$ columns, the CMAQ model, ground-level in-situ measurements, and a method to derive the ground-level $\mathrm{NO}_{2}$ concentrations by combining OMI tropospheric $\mathrm{NO}_{2}$ columns and the CMAQ model. Comparisons of the derived $\mathrm{NO}_{2}$ with ground-based $\mathrm{NO}_{2}$ concentrations and model simulations in China are given in Section 3. A discussion and conclusion are given in Sections 4 and 5, respectively.

\section{Materials and Methods}

\subsection{Measurement of OMI Tropospheric $\mathrm{NO}_{2}$ Columns}

The Dutch-Finnish OMI installed on NASA's EOS Aura satellite is a nadir-viewing imaging spectrograph that measures direct and atmosphere-backscattered sunlight within an ultraviolet-visible (UV-VIS) range of $270 \mathrm{~nm}$ to $500 \mathrm{~nm}$ [26]. EOS Aura was launched on 15 July 2004, and it traces a sun-synchronous polar orbit at approximately $705 \mathrm{~km}$ altitude over a period of $100 \mathrm{~min}$ and with a local equator crossing time of between 13:40 and 13:50, local time [31]. The OMI instrument is equipped with two two-dimensional Charge Coupled Device (CCD) detectors. The CCDs record the complete 270-500 nm spectrum in one direction and observe the Earth's atmosphere with a $114^{\circ}$ field of view that is distributed over 60 discrete viewing angles, and which is perpendicular to the flight direction. The OMI's wide field of view corresponds to a $2600 \mathrm{~km}$-wide spatial swath across the Earth's surface, which is large enough to achieve complete global coverage once a day. The exposure time of the CCD-camera is $2 \mathrm{~s}$, corresponding to a spatial sampling of $13 \mathrm{~km}$ along the track $(2 \mathrm{~s} \times 6.5 \mathrm{~km} / \mathrm{s}$, with the latter being the orbital velocity projected onto the Earth's surface). Along the cross track, OMI pixel sizes vary with viewing zenith angles from $24 \mathrm{~km}$ in the nadir to approximately $128 \mathrm{~km}$ in extreme viewing angles of $57^{\circ}$ along the edges of the swath [31].

Detailed descriptions of the $\mathrm{NO}_{2}$ retrieval algorithm were provided by Boersma et al. [32], Bucsela et al. [33] and Celarier et al. [34]. The $\mathrm{NO}_{2}$ retrieval algorithm involves a two-step procedure [31]. 
The first step employs a standard Differential Optical Absorption Spectroscopy (DOAS) technique [35] to determine slant column densities with a nonlinear least squares fitting within the $415-465 \mathrm{~nm}$ windows. The slant column represents the integrated abundance of $\mathrm{NO}_{2}$ along the average photon path through the atmosphere. The second step is to derive initial vertical column densities by dividing slant column densities with an unpolluted air mass factor (AMF), which is defined as the ratio of the observed slant column to the vertical column. The AMF can be calculated using a single mean unpolluted $\mathrm{NO}_{2}$ profile, and it estimates the stratospheric contributions to slant columns, which can be made by assimilating slant columns into the Thematic Mapper 4 (TM4) atmospheric Chemical Transport Model (CTM), including stratospheric chemistry and meteorological fields.

Major errors in the retrieval of tropospheric $\mathrm{NO}_{2}$ columns have been estimated at $\sim 0.7 \times 10^{15} \mathrm{~mol} \mathrm{~cm}^{-2}$ from the slant column fitting $\left(\sim 0.15 \times 10^{15} \mathrm{~mol} \mathrm{~cm}^{-2}\right.$ in the stratospheric slant column and $\sim 0.5 \times 10^{15}-1.5 \times 10^{15} \mathrm{~mol} \mathrm{~cm}^{-2}$ in the tropospheric AMF for individual cloud-free pixels (with an effective cloud fraction of $<0.2$ ) [31]. AMF errors are primarily caused by cloud interference, surface albedo, aerosol, and profile shape uncertainties [29,30,32,36,37]. Error contributions to relative tropospheric AMF uncertainties (31\%) are reported to include the following: 15\% from surface albedo, $30 \%$ from cloud fractions, 15\% from cloud top pressure levels and $9 \%$ from profile shapes [31]. The separation between the stratosphere and troposphere also serves as a source of error, and while the overall error in the OMI vertical column density under clear and unpolluted conditions is estimated at $5 \%$, it can reach up to $50 \%$ in the presence of pollution and clouds [32]. Stripes affecting slant columns in the swath direction in Version 1.0.0 have been greatly reduced in Version 1.0.5, largely due to the improved dark current correction mechanisms that are available through Collection 3 Level 1B processing [38]. In this study we used the OMI standard tropospheric $\mathrm{NO}_{2}$ product (version 3.0) available from the NASA Goddard Earth Sciences (GES) Data Active Archive Center (http:/ / disc.sci.gsfc.nasa.gov/Aura/overview/data-holdings/OMI/). One year's worth of $\mathrm{OMI} \mathrm{NO}_{2}$ tropospheric columns data in 2014 in China were used because the ground-based $\mathrm{NO}_{2}$ measurements are available for validation. We used here the data taken at an effective cloud fraction of $<0.2$. We used OMI tropospheric $\mathrm{NO}_{2}$ columns covering an area of $18^{\circ} \mathrm{N}-55^{\circ} \mathrm{N}$ and $70^{\circ} \mathrm{E}-138^{\circ} \mathrm{E}$.

\subsection{Model Description}

The two main components of the modeling system are Community Multi-scale Air Quality (CMAQ), developed by the US Environmental Protection Agency (US EPA) to simulate multiple atmosphere quality issues with multi-scale capabilities [39], and Regional Atmospheric Modeling System (RAMS). CMAQ is a multi-scale and multi-pollutant air quality model developed for depicting the detail processes about dust formation, transport, deposition, and other important characteristics [40]. The comprehensive suite aerosol composition (sulfate, nitrate, ammonium, black carbon, organic mass, dust and sea salt) is taken into consideration. The aerosol particle size distribution is comprised of three modes: Aitken mode, accumulation mode, and coarse mode. In this study the chemical mechanism CB05 [41] and aerosol evaluation processes of CMAQ Version 4.7 is used.

RAMS is a multifunctional numerical code for simulating and forecasting meteorological phenomena, and has good capacity to depict the boundary layer, which is important for simulating the dust formation. In this study, RAMS is used to provide the three-dimensional meteorological field for CMAQ, including boundary-layer turbulence, cloud, precipitation, and other meteorological elements. The meteorological fields from RAMS are used instead of the CMAQ default meteorological driver. In this study, the RAMS was run in a four-dimensional data assimilation mode along with re-initialization every 4 days, with the first $24 \mathrm{~h}$ designated as the initialization period. The three-dimensional meteorological fields of the RAMS were obtained from the European Center for Medium-Range Weather Forecast (ECMWF) datasets, which were available every $6 \mathrm{~h}$ with a spatial resolution of $1^{\circ} \times 1^{\circ}$. Many previous works have shown the successful use of the RAMS-CMAQ modeling system by comparing the simulation results with diverse measurement data [42-45]. 
In this study, the emission inventory by the RAMS-CMAQ modeling system is introduced as follows. The anthropogenic emissions of aerosols and their precursors $\left(\mathrm{CO}, \mathrm{NOx}, \mathrm{SO}_{2}\right.$, volatile organic compounds (VOCs), black carbon, organic carbon, $\mathrm{PM}_{2.5}$, and $\mathrm{PM}_{10}$ ) are obtained from the monthly-based emission inventory [46-48], updated from the previous version [49], over East Asia. This emission inventory has a spatial resolution of $0.25^{\circ} \times 0.25^{\circ}$ and involves four emission categories, including industry, power, transport and residential. The model domain (Figure 1) is on a rotated polar stereographic map projection centered at $\left(35^{\circ} \mathrm{N}, 116^{\circ} \mathrm{E}\right)$ with a $64 \mathrm{~km}$ grid cell. The modeling system has 15 vertical layers in the coordinates system unequally spaced from the ground to $\sim 23 \mathrm{~km}$, and approximately half of them are concentrated in the lowest $2 \mathrm{~km}$ to improve the simulation of the atmospheric boundary layer. Research has shown that the $\mathrm{NO}_{2}$ concentrations in China modeled using the RAMS-CMAQ modeling system are generally in good agreement with surface observations and satellite measurements [50-53].

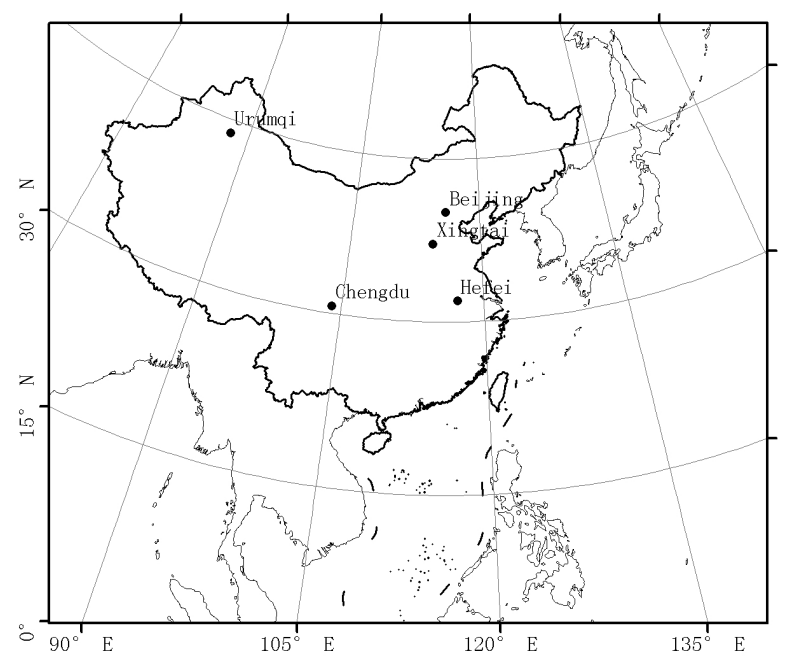

Figure 1. Model domain for RAMS-CMAQ used in this study is on a rotated polar stereographic map projection centered at $\left(35^{\circ} \mathrm{N}, 116^{\circ} \mathrm{E}\right)$ with a $64 \mathrm{~km}$ grid cell.

\subsection{Ground-Level In Situ Measurement}

Along with the rapid economic growth that has occurred over the past two decades, environmental pollution has emerged as a severe issue in China. The Chinese government has established the China National Environmental Monitoring Centre (CNEMC), which is directly affiliated with the ministry of environmental protection of the People's Republic of China. CNEMC's main functions are to undertake state environmental monitoring, develop state environmental monitoring technologies, and provide monitoring information and technical support to the country's environmental management and decision-making bodies. Since the beginning of 2013, CNEMC has begun to establish a network for monitoring ground-level $\mathrm{NO}_{2}$ concentrations over China. Currently, there are more than 800 atmospheric pollution-monitoring stations in this network, hourly ground-level $\mathrm{NO}_{2}$ concentrations released by these monitoring stations were measured with the standard methods (http://www.cnemc.cn/publish/totalWebSite/0493/187/newList_1.html). The Thermo Scientific Model $42 \mathrm{i}$, which is used to monitor ground-level $\mathrm{NO}_{2}$ concentrations in these monitoring stations, is designated by the United States Environmental Protection Agency (US EPA) as a Reference Method for the measurement of ambient concentrations of $\mathrm{NO}_{2}$ pursuant with the requirements defined in the Code of Federal Regulations. The Model 42i Chemiluminescence Analyzer combines proven detection technology, easy-to-use menu-driven software, and advanced diagnostics to offer unsurpassed flexibility and reliability. We found that the 2014 annual observation data is the most abundant, and has the minimum discontinuity after statistics. 
In this study, we used ground-level $\mathrm{NO}_{2}$ concentration observation data released by CNEMC-monitored stations in 2014 to compare. We first eliminated the data released by the CNEMC stations that had a monitoring time of less than 20 days a month. Then, we analyzed the longitude and latitude of each monitored station, computed the mean of the data released by stations distributed in the same $64 \mathrm{~km}$ grid cell according to latitude and longitude. In addition, because the OMI was launched into a Sun-synchronous orbit crossing the equator at approximately 13:45, we computed the mean of the CNEMC's ground-level $\mathrm{NO}_{2}$ concentration observation data between 13:00 and 14:00 as daily mean values to compare. In this study we obtained monthly mean values of ground-level $\mathrm{NO}_{2}$ concentrations released by 100 CNEMC monitored stations. Distribution of these 100 monitored stations is shown in Figure 2.

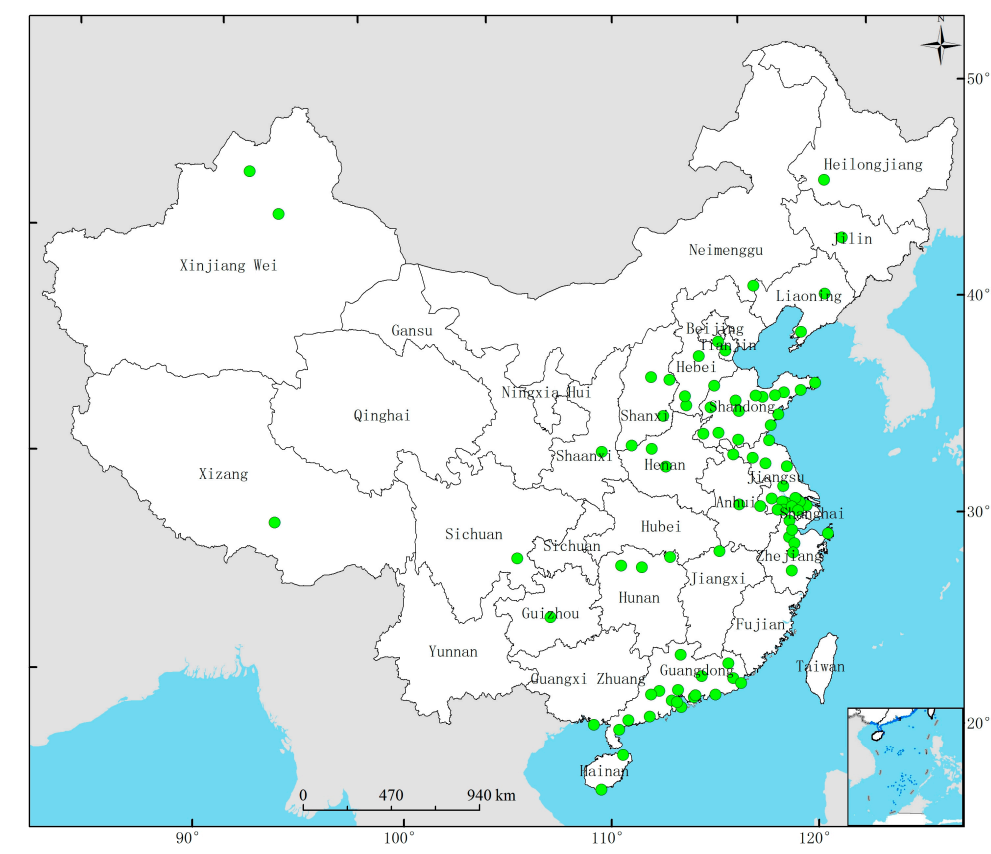

Figure 2. Distribution of the 100 ground-level $\mathrm{NO}_{2}$ concentrations CNEMC monitored stations.

\subsection{Determination of Ground-Level $\mathrm{NO}_{2}$ Concentrations}

Airborne measurements of the southeastern United States show that $\mathrm{NO}_{2}$ in the boundary layer can greatly contribute to $\mathrm{NO}_{2}$ tropospheric columns over polluted regions [54]. Retrievals based on satellite observations have revealed a close relationship between land surface $\mathrm{NO}_{2}$ emissions and tropospheric $\mathrm{NO}_{2}$ columns [36,55-59]. These studies clearly suggest that tropospheric $\mathrm{NO}_{2}$ columns retrieved from satellite observations can be used to derive the ground-level $\mathrm{NO}_{2}$ concentrations. In this study, we used the RAMS-CMAQ modeling system to simulate the relationship between satellite observations of tropospheric $\mathrm{NO}_{2}$ columns and the ground-level $\mathrm{NO}_{2}$ concentrations over China following the method described by Lamsal et al. [60,61], who conducted a simulation of tropospheric $\mathrm{NO}_{2}$ profiles over the United States and Canada using the Goddard Earth Observing System (GEOS)-Chem global three-dimensional model of tropospheric chemistry at $2^{\circ} \times 2.5^{\circ}$, version 7-03-06. However, previous research on ground-level $\mathrm{NO}_{2}$ concentrations by combining with satellite observations and model simulations has failed to consider the influence of China's high atmospheric pollution on obtaining the vertical distribution of tropospheric $\mathrm{NO}_{2}$ profiles over China. In addition, compared to the GEOS-Chem global model, the RAMS-CMAQ modeling system, with its higher spatial resolution of a $64 \mathrm{~km}$ grid cell, is more appropriate to simulating tropospheric $\mathrm{NO}_{2}$ profiles over China. Many works have shown that the modeled $\mathrm{NO}_{2}$ concentrations over China by the RAMS-CMAQ modeling system are more appropriately suited to China's high atmospheric pollution [51-53]. In this study we compensated for this shortcoming by estimating ground-level $\mathrm{NO}_{2}$ 
concentrations over China using the OMI standard $\mathrm{NO}_{2}$ product combined with simulations from the RAMS-CMAQ model, after obtaining the more appropriate vertical distribution of tropospheric $\mathrm{NO}_{2}$ profiles.

In this study, the different spatial resolution from the OMI standard $\mathrm{NO}_{2}$ product and simulation from the RAMS-CMAQ modeling system has hindered the estimating of ground-level $\mathrm{NO}_{2}$ concentrations over China. Our approach to reconstructing consistent spatial resolution was to degrade higher spatial resolution data to a single consistent coarse spatial resolution. Here we first calculated the distance of latitude and longitude from each grid cell of the RAMS-CMAQ model with relatively coarse spatial resolution of $64 \times 64 \mathrm{~km}^{2}$ grid cells to all grid cells of the OMI tropospheric $\mathrm{NO}_{2}$ columns with higher spatial resolution of $13 \times 24 \mathrm{~km}^{2}$, and considered the two grid cells of the different data with minimum distance of latitude and longitude to correspond to each other. Then we estimated ground-level $\mathrm{NO}_{2}$ concentrations over China using the OMI standard $\mathrm{NO}_{2}$ product combined with simulation from the RAMS-CMAQ model after reconstructing a consistent spatial resolution of $64 \times 64 \mathrm{~km}^{2}$.

\section{Results}

\subsection{Verification of Distributions of Tropospheric $\mathrm{NO}_{2}$ Profiles from $\mathrm{RAMS}-\mathrm{CM} A Q$}

In this section, verification of vertical distributions of tropospheric $\mathrm{NO}_{2}$ profiles from the RAMS-CMAQ model is presented. We first counted the monthly mean of tropospheric $\mathrm{NO}_{2}$ columns from OMI observations over China in 2014. After the corresponding unit conversion, we calculated the ratio of ground-level $\mathrm{NO}_{2}$ concentrations released by CNEMC to tropospheric $\mathrm{NO}_{2}$ columns by OMI, then compared the ratio of simulated $\mathrm{NO}_{2}$ concentrations distributed within the atmosphere from the ground to a height of $100 \mathrm{~m}$ to simulated concentrations distributed within the atmosphere from the ground to $\sim 23 \mathrm{~km}$ by the RAMS-CMAQ model. We verified the accuracy of the vertical distribution of tropospheric $\mathrm{NO}_{2}$ profiles over China from the RAMS-CMAQ model by comparing the correlation of these two sets of ratios, the results of which are shown in Figure 3.
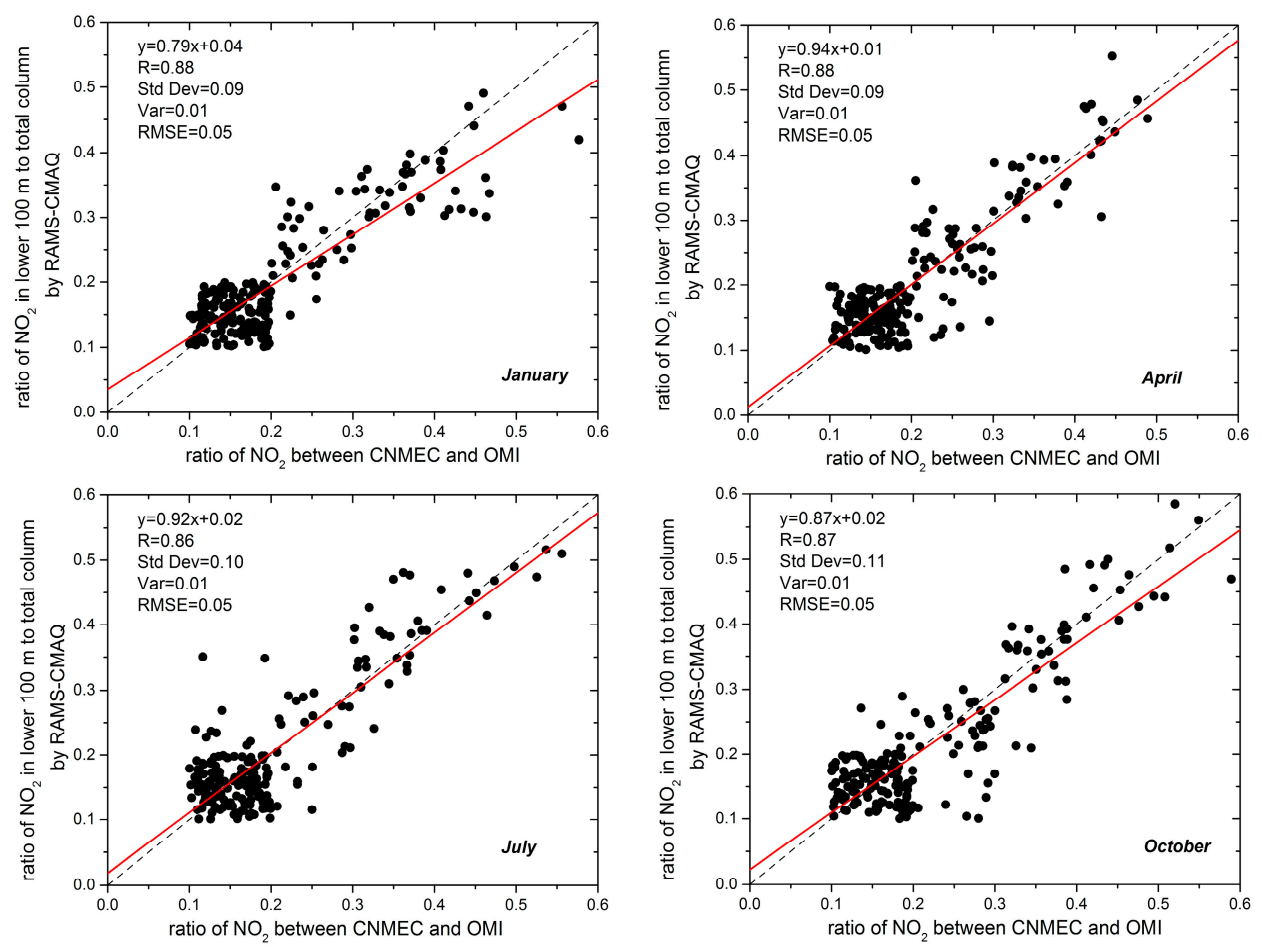

Figure 3. Scatter plots to verify accuracy of vertical distribution of tropospheric $\mathrm{NO}_{2}$ profiles over China from the RAMS-CMAQ model in January, April, July and October in 2014. 
It is found that the vertical distribution of tropospheric $\mathrm{NO}_{2}$ profiles over China has a large spatial and temporal variation. To illustrate these spatial-temporal variations in tropospheric $\mathrm{NO}_{2}$ profiles over China, we chose to analyze the vertical distributions of tropospheric $\mathrm{NO}_{2}$ profiles in five representative cities: Beijing, Xingtai, Chengdu, Urumqi and Hefei. Information on these five cities is listed in Table 1. The vertical distributions of tropospheric $\mathrm{NO}_{2}$ profiles in these five cities are shown in Figure 4. The $x$-axis shows $\mathrm{NO}_{2}$ concentrations simulated by the RAMS-CMAQ modeling system, and the $y$-axis shows the corresponding heights expressed by the natural logarithm. Natural logarithm height was used because the vertical layers by the RAMS-CMAQ modeling system were unequally spaced in the coordinates system, and heights corresponding to the different vertical layers varied dramatically. It is evident from Figure 4 that the tropospheric $\mathrm{NO}_{2}$ columns are mainly distributed within the atmosphere from the ground to a height of 100-150 m.

Table 1. The information of the selected five cities.

\begin{tabular}{cccl}
\hline City Name & Latitude & Longitude & \multicolumn{1}{c}{ City Condition } \\
\hline Beijing & $40.00^{\circ}$ & $116.00^{\circ}$ & $\begin{array}{l}\text { a megalopolis located in northeastern China that presents } \\
\text { relatively high levels of air pollution }\end{array}$ \\
\hline Xingtai & $37.05^{\circ}$ & $114.48^{\circ}$ & $\begin{array}{l}\text { one of the most air-polluted cities in China, and an important } \\
\text { energy base in the North China area }\end{array}$ \\
\hline Chengdu & $30.67^{\circ}$ & $104.06^{\circ}$ & $\begin{array}{l}\text { a large city located in southwestern China with relatively high air } \\
\text { pollution compared to other southwestern cities }\end{array}$ \\
\hline Urumqi & $43.77^{\circ}$ & $87.68^{\circ}$ & $\begin{array}{l}\text { a large city located in northwestern China but with lower levels of } \\
\text { air pollution compared to other cities located in the east } \\
\text { Hefei }\end{array}$ \\
\hline $31.86^{\circ}$ & $117.27^{\circ}$ & $\begin{array}{l}\text { a large city located in southeastern China with relatively low } \\
\text { levels of air pollution compared to other cities located in the north }\end{array}$ \\
\hline
\end{tabular}
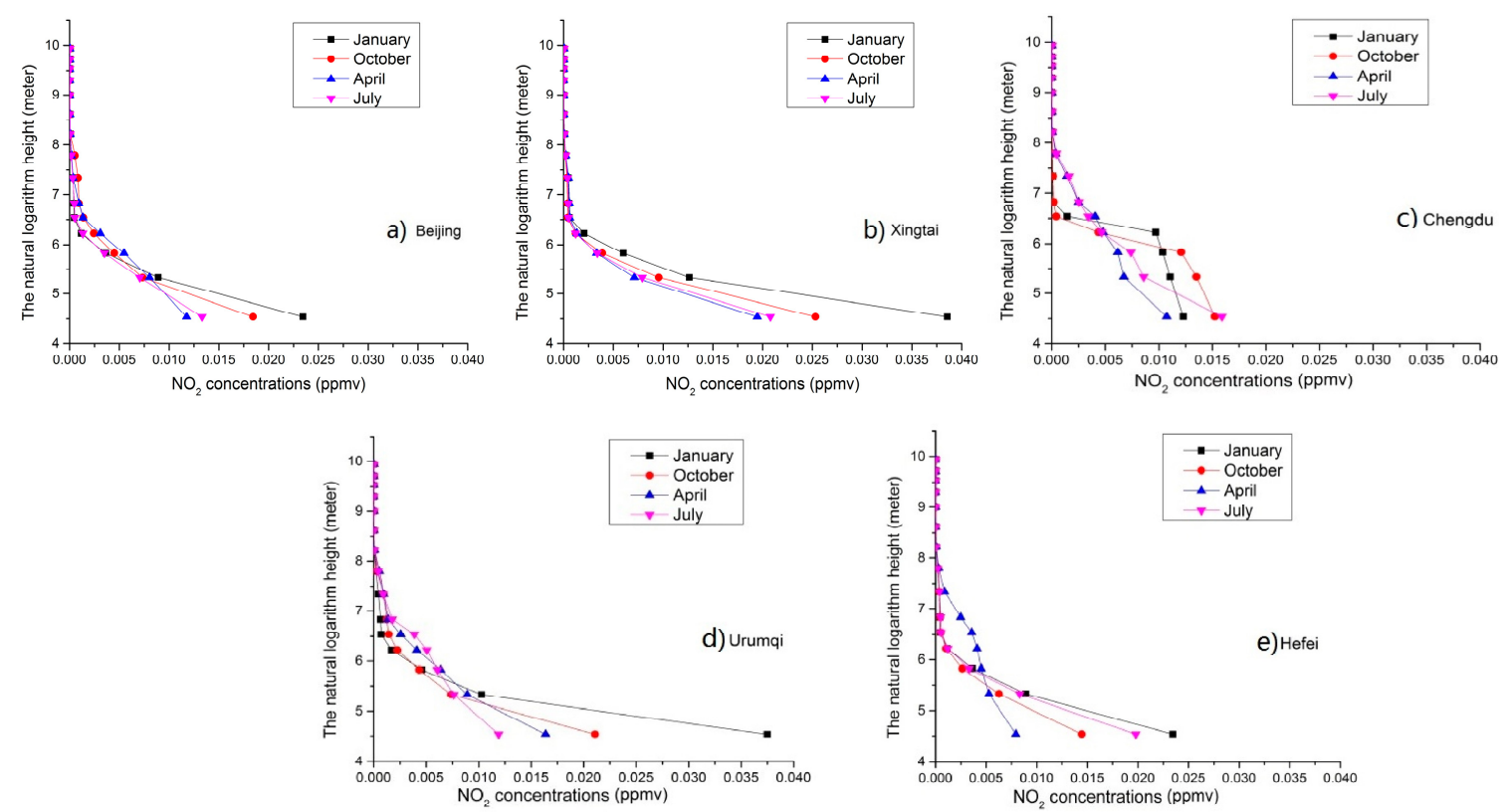

Figure 4. The simulated $\mathrm{NO}_{2}$ vertical profiles over Beijing (a), Xingtai (b), Chengdu (c), Urumqi (d) and Hefei (e) in January, April, July and October in 2014.

\subsection{Spatial-Temporal Variations of Derived Ground-Level $\mathrm{NO}_{2}$ Concentrations}

In this section, spatio-temporal variation trends of derived ground-level $\mathrm{NO}_{2}$ concentrations combining OMI observations with the RAMS-CMAQ model are presented. Figure 5 shows the monthly mean values of the derived ground-level $\mathrm{NO}_{2}$ concentrations over China in January, April, 
July, and October, 2014. From Figure 5, we can see that among different seasons the ground-level $\mathrm{NO}_{2}$ concentration levels over China were high in the winter/spring and low in the summer/fall, and for different regions they were high in the eastern, developed areas, but low in the western, developing areas of China, due to there being more anthropogenic emissions in the eastern areas (e.g., ground-level $\mathrm{NO}_{2}$ concentrations in the developed North China Plain reached $60.00-100.00 \mu \mathrm{g} / \mathrm{m}^{3}$ whereas concentrations in the less developed western areas reached $5.00-20.00 \mu \mathrm{g} / \mathrm{m}^{3}$ ). We analyzed these spatial distribution characteristics of ground-level $\mathrm{NO}_{2}$ concentrations for China in combination with industrial development and anthropogenic emissions. A significant positive correlation was found between the magnitude of ground-level $\mathrm{NO}_{2}$ concentrations and levels of industrial development and anthropogenic emissions. Of the different seasons in China, winter ground-level $\mathrm{NO}_{2}$ concentration values are the highest of the year, which is mainly attributable to winter coal use for heating.
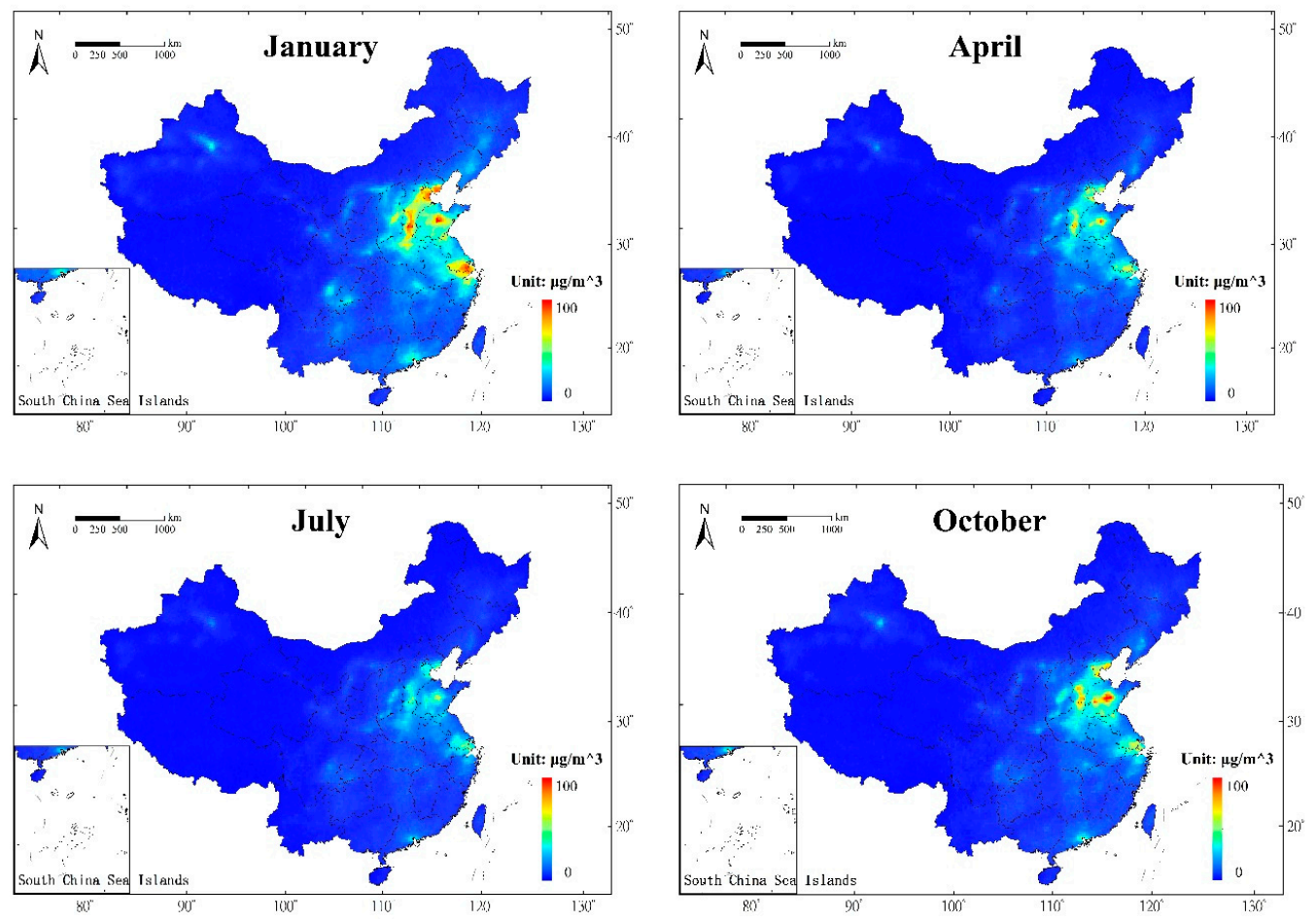

Figure 5. Monthly derived ground-level $\mathrm{NO}_{2}$ concentrations over China in January, April, July, and October in 2014.

\subsection{Comparisons of the Derived $\mathrm{NO}_{2}$ with Ground-Based Measurements for Different Regions}

A comparison between monthly mean ground-level $\mathrm{NO}_{2}$ concentrations for different regions from in-situ measurements and the concentrations derived from OMI satellite data in conjunction with the RAMS-CMAQ modeling results is shown in Figure 6, the $x$-axis is the month, and the $y$-axis is the ground-level $\mathrm{NO}_{2}$ concentrations. We analyzed the ground-level $\mathrm{NO}_{2}$ concentrations in the five representative cities, i.e., Beijing, Xingtai, Chengdu, Urumqi and Hefei. As the CNEMC atmospheric pollution monitoring stations are unevenly distributed across the country, we first computed the average values of ground-level $\mathrm{NO}_{2}$ concentrations released by all monitoring stations distributed within a city, calculated the average value of OMI tropospheric $\mathrm{NO}_{2}$ columns over the same city, and then we obtained the ground-level $\mathrm{NO}_{2}$ concentrations of the same city. Figure 6 shows that the average correlation coefficients largely fall within a range of $0.70 \sim 0.80$ for the selected five representative cities of Beijing, Xingtai, Chengdu, Urumqi and Hefei, and that the correlation coefficients for Beijing, Xingtai and Hefei are, relatively, better. Beijing is one of China's mega cities and has, relatively, more ground monitoring stations. The data quality in Beijing is better, creating a more solid foundation 
for air pollution monitoring research and long-term monitoring. Xingtai is currently one of the most heavily air-polluted cities in China, and the air quality levels in Xingtai were ranked last. Hefei's air is similar to Beijing. Figure 6 shows that our method is more precise at determining levels for cities with heavy air pollution, and for those cities with more ground monitoring stations. In general the vertical distributions of tropospheric $\mathrm{NO}_{2}$ profiles for these cities based on the RAMS-CMAQ model are, relatively, more accurate representations of air quality conditions; therefore, ground-level $\mathrm{NO}_{2}$ concentrations retrieved are more accurate.

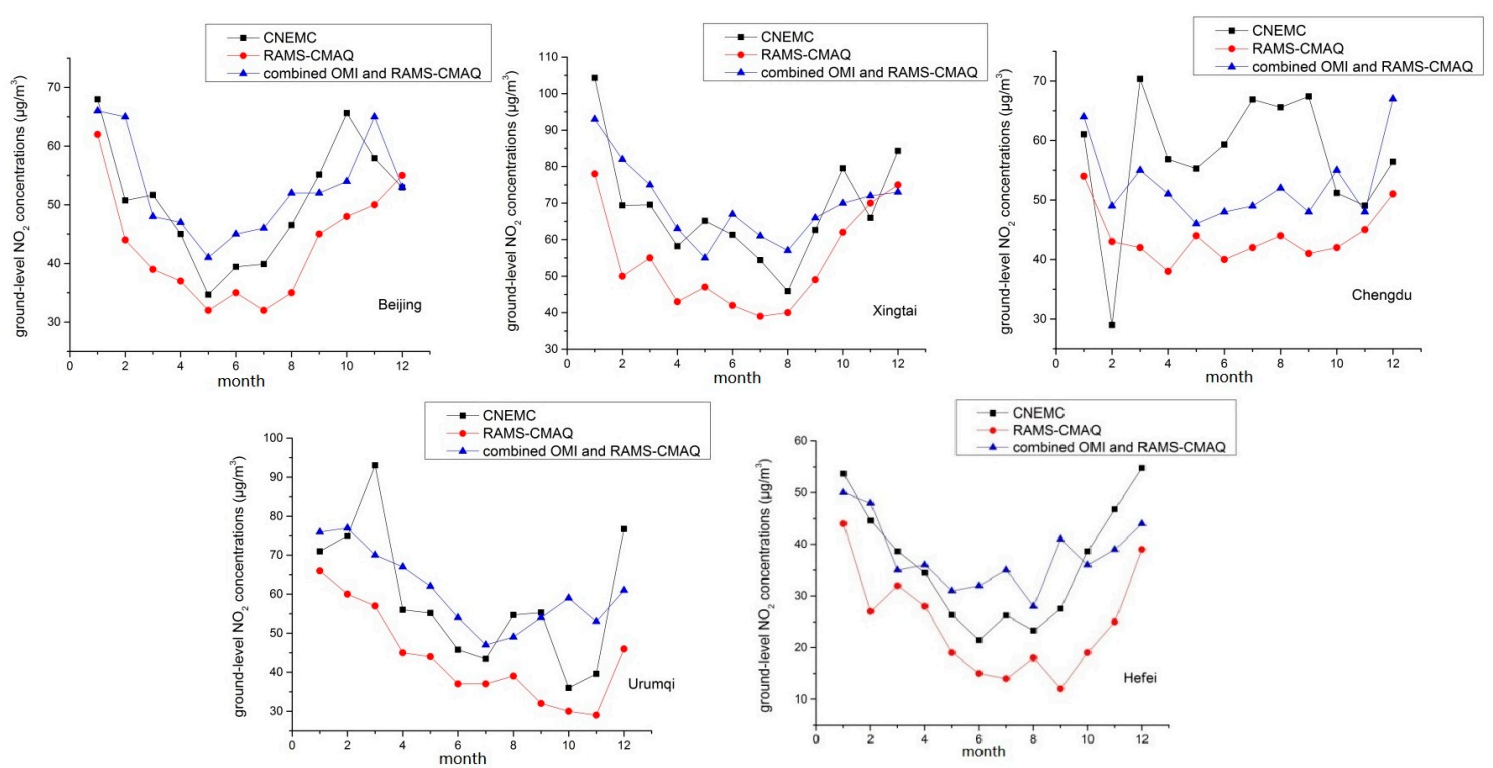

Figure 6. Line charts of the derived ground-level $\mathrm{NO}_{2}$ concentrations with in-situ measurements from ground network and the RAMS-CMAQ simulation over Beijing, Xingtai, Chengdu, Urumqi and Hefei cities in 2014.

From Figure 6, we also found that, compared to the in-situ ground measurements, the RAMS-CMAQ simulated values are underestimated, and in areas with high $\mathrm{NO}_{2}$ concentrations, the underestimations are more obvious (e.g., in Xingtai City). Overall, the results of our method are similar to the in-situ measurements. The standard deviation between ground-level $\mathrm{NO}_{2}$ concentrations, the RAMS-CMAQ simulated measurements and those measurements released by CNEMC in Beijing was $10.25 \mu \mathrm{g} / \mathrm{m}^{3}$, and the standard deviation between our method and CNEMC's was $9.03 \mu \mathrm{g} / \mathrm{m}^{3}$. The variance between the RAMS-CMAQ and CNEMC data for Beijing was 105.01, and the variance between our method and that of CNEMC was 81.51. The standard deviation between the RAMS-CMAQ simulated measurements and those released by CNEMC for Xingtai was $15.68 \mu \mathrm{g} / \mathrm{m}^{3}$, and the standard deviation between our method and that released by CNEMC was $12.65 \mu \mathrm{g} / \mathrm{m}^{3}$. The variance between the RAMS-CMAQ model and CNEMC results for Xingtai was 246.00, and the variance between our method and that of CNEMC was 160.07. The analysis shows that ground-level $\mathrm{NO}_{2}$ concentrations derived using OMI tropospheric $\mathrm{NO}_{2}$ columns together with vertical distributions of tropospheric $\mathrm{NO}_{2}$ profiles from RAMS-CMAQ model simulations were more accurate than the simulations from RAMS-CMAQ model only.

Figure 6 shows the derived ground-level $\mathrm{NO}_{2}$ concentrations by OMI and RAMS-CMAQ model are generally lower than the in-situ ground measurements by CNEMC in these cities in winter, except for Chengdu, this result is similar to Lamsal's result that the derived surface $\mathrm{NO}_{2}$ by OMI and GEOS-chem over western North America are generally lower than the local in-situ measurements in winter [60]. Larger differences between the in-situ measurements and the derived ground-level $\mathrm{NO}_{2}$ concentrations in China likely reflect a combination of enhanced spatial variations in polluted regions and preferential placement of in-situ monitors in polluted locations. The ground-level 
$\mathrm{NO}_{2}$ concentrations estimated from our approach are generally consistent with the in-situ ground measurements for these five cities, and the occasional large discrepancies may reflect local variation processes. In addition, the consumption of bulk coal and household coal for heating, cooking and other uses in winter is common in China, especially in rural areas. However, information about these sources of $\mathrm{NO}_{2}$ emissions are generally not grasped by the government. The emission inventory by the RAMS-CMAQ model generally also overlooks wintertime $\mathrm{NO}_{2}$ emission caused by bulk coal and household coal in China, which led to the underestimation of the derived ground-level $\mathrm{NO}_{2}$ concentrations in winter from our approach. The vertical distribution of tropospheric $\mathrm{NO}_{2}$ profiles over China from the RAMS-CMAQ model as shown in Figure 3 also verified this underestimation of our results. Chengdu is surrounded by mountains. From west to east, the terrain of Chengdu is divided into three parts, comprising mountains, plains and hills. It is difficult to operate the local in-situ $\mathrm{NO}_{2}$ measurements such as the elevation of the western part of Chengdu is mainly over $3 \mathrm{~km}$ while the elevation of the central part is about $400 \mathrm{~m}$ to $700 \mathrm{~m}$. However, in order to ensure the integrity of this study, it is necessary to study ground-level $\mathrm{NO}_{2}$ concentration in Chengdu, which is a representative metropolis in Southwest China. Meanwhile, the worse result in Chengdu reflects that our approach has to be improved when considering complicated topographies, which is a future work we will conduct. Additionally, more ground-based monitoring data will be helpful for future analysis.

\subsection{Comparisons of the Derived $\mathrm{NO}_{2}$ with Ground-Based Measurements for Different Seasons}

In this section, we compared the ground-level $\mathrm{NO}_{2}$ concentrations retrieved from our method with in-situ measurements for different seasons across China. As satellite data offer broader observational data coverage than in-situ measurements, data in a large area of China and for different seasons were used. We used mean monthly values from the 100 ground-level $\mathrm{NO}_{2}$ concentration CNEMC-monitored stations mentioned in Section 2.3 to compare. Figure 7 shows good correlations between the derived ground-level $\mathrm{NO}_{2}$ concentrations and the monthly mean ground-level $\mathrm{NO}_{2}$ over China for 2014 . The correlation coefficient, $\mathrm{R}$, was 0.80 for January and was 0.78 for July; compared to ground-level $\mathrm{NO}_{2}$ concentrations simulated using the RAMS-CMAQ model only. The standard deviation between our method and those measurements released by CNEMC for January was $18.90 \mu \mathrm{g} / \mathrm{m}^{3}$, and the standard deviation between the RAMS-CMAQ simulated measurements and CNEMC's was $21.79 \mu \mathrm{g} / \mathrm{m}^{3}$. The variance between our method and that released by CNEMC for January was 257.19, and the variance between the RAMS-CMAQ and CNEMC data was 353.09. The standard deviation between our method and that released by CNEMC for July was $11.31 \mu \mathrm{g} / \mathrm{m}^{3}$, and the standard deviation between the RAMS-CMAQ simulated concentrations and CNEMC's was $12.11 \mu \mathrm{g} / \mathrm{m}^{3}$. The variance between our method and that released by CNEMC for July was 127.96, and the variance between the RAMS-CMAQ and CNEMC data was 146.59. Analyzing the ground-level $\mathrm{NO}_{2}$ concentrations retrieved from our method for different seasons, we found clear seasonal variations in the derived ground-level $\mathrm{NO}_{2}$ concentrations, with the largest variations occurring in the winter and the least pronounced in the summer. This is mainly attributable to increases in burning and heating emissions in the winter. Therefore, anthropogenic emission is the main factor that is impacting changes in ground-level $\mathrm{NO}_{2}$ concentrations. The ground-level $\mathrm{NO}_{2}$ concentrations calculated in this paper can be used to measure the influence of anthropogenic emissions on atmospheric quality.

Figure 7 also shows that the ground-level $\mathrm{NO}_{2}$ concentrations estimated by OMI and RAMS-CMAQ model are generally lower than the in-situ measurements by CNEMC over China in January and July, the underestimation of the derived ground-level $\mathrm{NO}_{2}$ concentrations in January from our approach may be caused by the wintertime consumption of bulk coal and household coal in China, which are not considered in the emission inventory by the RAMS-CMAQ model. The underestimation level of the derived ground-level $\mathrm{NO}_{2}$ concentrations in July is lower than in January, which corresponds to the underestimation level of the vertical distributions of tropospheric $\mathrm{NO}_{2}$ profiles as shown in Figure 3. OMI-derived ground-level $\mathrm{NO}_{2}$ concentration represents the mean concentration over several hundred square kilometers, while in-situ measurements are point 
observations in general, which led to a slope of linear regression line of less than 1 in Figure 7. Possible explanations for the seasonal discrepancy between the derived ground-level $\mathrm{NO}_{2}$ concentrations and in-situ measurements include errors in the in-situ $\mathrm{NO}_{2}$ concentrations, in the RMAS-CMAQ simulated vertical distributions of tropospheric $\mathrm{NO}_{2}$ profiles, and in the OMI tropospheric $\mathrm{NO}_{2}$ column retrieval. Another likely contributor to the seasonal discrepancy is the use of mean $\mathrm{NO}_{2}$ profiles in the OMI air mass factor calculation [60]. Seasonal variation would yield an underestimate in retrieved $\mathrm{NO}_{2}$ columns in winter versus in summer. In addition, seasonal variation in surface reflectivity could also play a part.
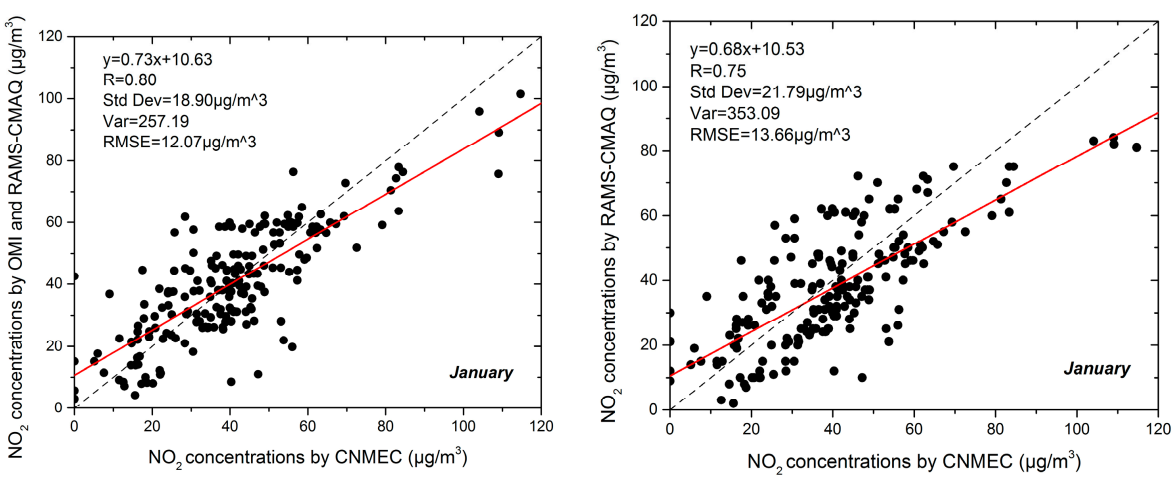

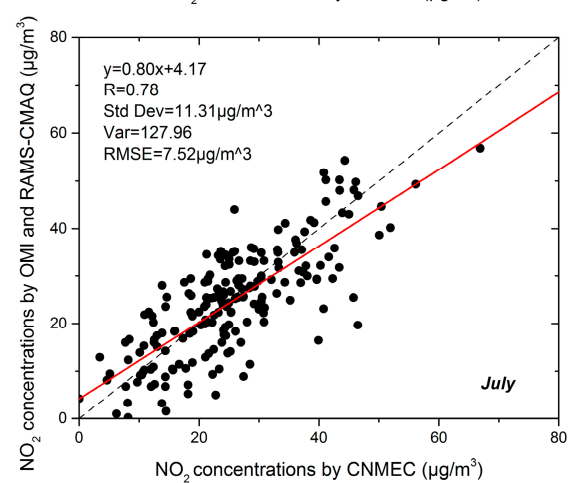

(a)

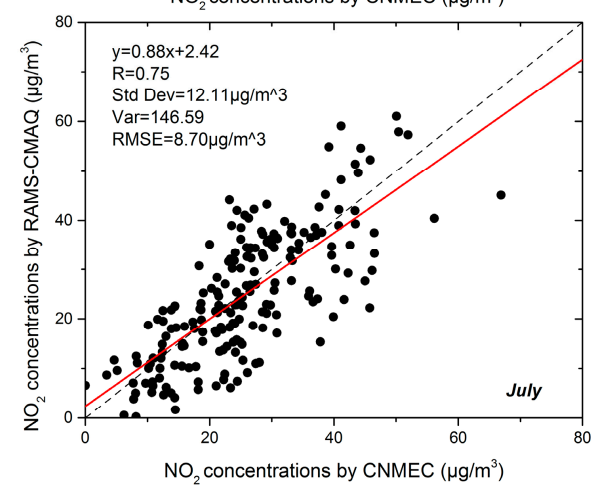

(b)

Figure 7. Scatter plots of the derived ground-level $\mathrm{NO}_{2}$ concentrations with in-situ measurements from ground network (a) and the RAMS-CMAQ simulation (b) over China in January and July 2014.

\section{Discussion}

In this study, we have used the OMI tropospheric $\mathrm{NO}_{2}$ columns and the RAMS-CMAQ modeling system to infer ground-level $\mathrm{NO}_{2}$ concentrations. Several previous studies reported that the simulation of tropospheric $\mathrm{NO}_{2}$ profiles over the United States and Canada using the GEOS-Chem global three-dimensional model of tropospheric chemistry at $2^{\circ} \times 2.5^{\circ}$ were obtained, and ground-level $\mathrm{NO}_{2}$ concentrations over the United States and Canada were measured by the Ozone Monitoring Instrument (OMI) $[60,61]$. However, these previous studies on ground-level $\mathrm{NO}_{2}$ concentrations by combining satellite observations and model simulations, on the one hand, has not been implemented in China, and the influence of severe atmospheric pollution also increases the level of difficulty of obtaining the vertical distribution of tropospheric $\mathrm{NO}_{2}$ profiles over China. On the other hand, compared to the GEOS-Chem global model used in the previous studies, the RAMS-CMAQ modeling system with the higher spatial resolution of $64 \mathrm{~km}$ grid cell is more appropriate for simulating tropospheric $\mathrm{NO}_{2}$ profiles over China. Much research has shown that the modeled $\mathrm{NO}_{2}$ concentrations over China by the RAMS-CMAQ model are more appropriate to China's high atmospheric pollution [51-53]. In this study we inferred the ground-level $\mathrm{NO}_{2}$ concentrations over China using the $\mathrm{OMI} \mathrm{NO}$ product 
combined with simulation from the RAMS-CMAQ model after obtaining the more appropriately vertical distribution of tropospheric $\mathrm{NO}_{2}$ profiles.

We derived the ground-level $\mathrm{NO}_{2}$ concentrations using the total column of $\mathrm{NO}_{2}$ observed from the OMI and the simulations from the RAMS-CMAQ model in China. Data for 2014 were processed and compared to in-situ measurements derived from the CNEMC monitoring network. The derived ground-level $\mathrm{NO}_{2}$ concentrations were also compared with the simulated ground-level $\mathrm{NO}_{2}$ concentrations by the RAMS-CMAQ. Overall, ground level $\mathrm{NO}_{2}$ concentrations were underestimated by the RAMS-CMAQ model. Using observed data corresponding to in-situ CNEMC measurements, the standard deviation between the RAMS-CMAQ simulated measurements and in-situ measurements by CNEMC for January was $21.79 \mu \mathrm{g} / \mathrm{m}^{3}$, it was improved to $18.90 \mu \mathrm{g} / \mathrm{m}^{3}$ between our method and CNEMC data. The variance between our method and that released by CNEMC for January was 257.19, and the variance between the RAMS-CMAQ and CNEMC data was 353.09, the root mean square error between the RAMS-CMAQ simulations and in-situ measurements by CNEMC for January was $13.66 \mu \mathrm{g} / \mathrm{m}^{3}$, which was improved to $12.07 \mu \mathrm{g} / \mathrm{m}^{3}$ between our method and CNEMC data. The standard deviation between the RAMS-CMAQ and CNEMC data for July was $12.11 \mu \mathrm{g} / \mathrm{m}^{3}$, and it was improved to $11.31 \mu \mathrm{g} / \mathrm{m}^{3}$ between our method and CNEMC data. The variance between our method and that released by CNEMC for July was 127.96, and the variance between the RAMS-CMAQ data and CNEMC data was 146.59. The root mean square error between the RAMS-CMAQ simulations and in-situ measurements by CNEMC for July was $8.70 \mu \mathrm{g} / \mathrm{m}^{3}$, which was improved to $7.52 \mu \mathrm{g} / \mathrm{m}^{3}$ between our method and CNEMC data. Correlation coefficients between the RAMS-CMAQ simulation and in-situ measurements were 0.75 for January and July, and they were improved to 0.80 and 0.78 , respectively, from our approach. Compared to that of the in-situ measurements in different regions, the standard deviation between ground-level $\mathrm{NO}_{2}$ concentrations, the RAMS-CMAQ simulated measurements, and in-situ measurements released by CNEMC in Beijing was $10.25 \mu \mathrm{g} / \mathrm{m}^{3}$, which was improved to $9.03 \mu \mathrm{g} / \mathrm{m}^{3}$ between our method and CNEMC data33; the standard deviation between the RAMS-CMAQ and CNEMC data in Xingtai was $15.68 \mu \mathrm{g} / \mathrm{m}^{3}$, which was improved to $12.65 \mu \mathrm{g} / \mathrm{m}^{3}$ between our method and CNEMC data.

Major errors in the retrieval of ground-level $\mathrm{NO}_{2}$ concentrations using the total column of $\mathrm{NO}_{2}$ observed from the OMI and the simulations from the RAMS-CMAQ model have been estimated in the following aspects. First, the errors in the retrieval of OMI tropospheric $\mathrm{NO}_{2}$ columns have been estimated at $\sim 0.7 \times 10^{15} \mathrm{~mol} \mathrm{~cm}^{-2}$ from the slant column fitting $\left(\sim 0.15 \times 10^{15} \mathrm{~mol} \mathrm{~cm}^{-2}\right.$ in the stratospheric slant column and $\sim 0.5 \times 10^{15}-1.5 \times 10^{15} \mathrm{~mol} \mathrm{~cm}^{-2}$ in the tropospheric AMF for individual cloud-free pixels (with an effective cloud fraction of $<0.2$ )) [31]. AMF errors are mainly from cloud interference, surface albedo, aerosol, and profile shape uncertainties [29,30,32,36,37]. Separation between the stratosphere and troposphere is also a source of error; and while the overall error in the OMI vertical $\mathrm{NO}_{2}$ columns under clear and unpolluted conditions is estimated at $5 \%$, it can reach up to $50 \%$ in the presence of pollution and clouds [32]. Second, in this study, we used the RAMS-CMAQ modeling system to simulate of tropospheric $\mathrm{NO}_{2}$ profiles over China. The emission inventory by the RAMS-CMAQ model, such as the anthropogenic emissions of aerosols and their precursors (CO, NOx, $\mathrm{SO}_{2}$, volatile organic compounds (VOCs), black carbon, and organic carbon, $\mathrm{PM}_{2.5}$, and $\mathrm{PM}_{10}$ ), are obtained from the monthly emission inventory [46-48] updated from the previous version [49] over East Asia. The errors in the retrieval of tropospheric $\mathrm{NO}_{2}$ profiles over China by the RAMS-CMAQ model are mainly due to the emission inventory and the meteorology field. The meteorology field is important to the modeled mass concentrations, aerosols and their precursor simulations. The accuracy of wind field and relative humidity simulation could obviously affect the dust particle transport and optical properties calculation [50]. Last, because the different spatial resolution from the OMI standard $\mathrm{NO}_{2}$ product and simulation from the RAMS-CMAQ model has hindered the estimating ground-level $\mathrm{NO}_{2}$ concentrations, another source of error was the reconstructed consistent spatial resolution, for which we degraded the higher spatial resolution data to a single consistent coarse spatial resolution. 
In this study, we did not take into account the averaging kernel (AK). AK is a well-established concept in the retrieval of remote sensing observations as the link between the retrieved quantities and reality. It is proportional to the height-dependent sensitivity of satellite observation to changes in tracer concentration, and provides the interpretation of the value of the air mass factor. The AK provides important information needed for quantitative analysis of the satellite data, especially for interpreting the satellite retrieval of trace gases to users. It's very useful to remove the dependence on a priori assumptions about the profile shape for inter-comparison between model simulations and satellite measurements. In this paper, we focused on estimating ground-level $\mathrm{NO}_{2}$ by combining the OMI standard product OMNO2 from NASA (Version 3) and the RAMS-CMAQ modeled $\mathrm{NO}_{2}$ profiles, rather than on satellite-model comparison, so we didn't consider the AK in this study. However, the $\mathrm{OMI} \mathrm{NO} 2$ standard product is not directly suitable to studying VCDs on a scale below the resolution of the ancillary parameters (such as $2^{\circ} \times 2.5^{\circ}$ for priori $\mathrm{NO}_{2}$ profiles), and the $\mathrm{AK}$ can be used to correct the $\mathrm{NO}_{2}$ VCDs when more accurate $\mathrm{NO}_{2}$ profiles are available, which will improve satellite $\mathrm{NO}_{2} \mathrm{VCD}$ products and also the ground-level nitrogen dioxide concentrations inferred from satellites. While this correction is beyond the scope of this study, we are developing a customized $\mathrm{OMI} \mathrm{NO}_{2}$ retrieval by recalculating AKs using the high-resolution RAMS-CMAQ modeled $\mathrm{NO}_{2}$ profiles, and will apply it to the estimation of ground-level $\mathrm{NO}_{2}$ in future study. We did not take into account $\mathrm{NO}_{2}$ emissions from natural sources such as biomass burning, soil, and lightning, because they are negligible compared to anthropogenic emissions over urban areas. In addition, the contribution of free tropospheric $\mathrm{NO}_{2}$ produced from lightning mainly occur in low latitude areas, while the $\mathrm{NO}_{2}$ high concentration areas, such as the Beijing Tianjin Hebei region, were mainly distributed in the middle and high latitude areas.

\section{Conclusions}

Most works using satellite observations of $\mathrm{NO}_{2}$ focused on tropospheric $\mathrm{NO}_{2}$ columns rather than on ground-level $\mathrm{NO}_{2}$ concentrations. However, ground-level $\mathrm{NO}_{2}$ concentrations are more closely related to anthropogenic emissions and directly affect human health. This paper presents a means of estimating ground-level $\mathrm{NO}_{2}$ concentrations based on OMI tropospheric $\mathrm{NO}_{2}$ columns and the vertical distribution of tropospheric $\mathrm{NO}_{2}$ profiles simulated using the RAMS-CMAQ model. One year's worth of data from 2014 was processed and the results were compared to ground-based $\mathrm{NO}_{2}$ measurements from a network of CNEMC, and the simulated ground-level $\mathrm{NO}_{2}$ concentrations by the RAMS-CMAQ model. Our results revealed that the method presented in this paper can be used to better measure ground-level $\mathrm{NO}_{2}$ concentrations over China.

Further analysis of the ground-level $\mathrm{NO}_{2}$ concentrations retrieved from this algorithm shows that seasonal variations of the ground-level $\mathrm{NO}_{2}$ concentrations are pronounced, with the largest occurring in the winter and the lowest in the summer. Such variations are mainly due to significant increases in burning and heating emissions levels in winter. The ground-level $\mathrm{NO}_{2}$ concentrations presented in this paper can be used to better measure distribution of $\mathrm{NO}_{2}$ in the atmosphere and study the effects of anthropogenic emissions on atmospheric pollution conditions. Further validations and improvements of this method are ongoing, and include the quality control of in-situ measurements, whose errors have not been taken into account. We plan to develop a simple empirical formula based on the CMAQ model for directly converting OMI column values to ground-level $\mathrm{NO}_{2}$. Such an algorithm may be used to more accurately monitor ground-level $\mathrm{NO}_{2}$ using satellite data and to generate measurements with better spatial and temporal coverage than surface measurements.

Acknowledgments: This work was supported by the National Natural Science Foundation of China (Grant No. 41501476) and the National Science and Technology Ministry (Grant No. 2014BAC21B03), this work was partially supported by China Postdoctoral Science Foundation funded project (Grant No. 2015M580084, 2016T90083). We greatly acknowledge the free use of tropospheric $\mathrm{NO}_{2}$ column data from the OMI sensor. We also thank State Key Laboratory of Atmospheric Boundary Layer Physics and Atmospheric Chemistry, Chinese Academy of Sciences for the RAMS-CMAQ simulation data. We also thank China's National Environmental Monitoring Centre for in-situ measurements.

Author Contributions: The authors contributed equally to the manuscript. 
Conflicts of Interest: The authors declare no conflict of interest.

\section{References}

1. Logan, J.A. Nitrogen Oxides in the Troposphere: Global and Regional Budgets. J. Geophys. Res. 1983, 88, 10785-10807. [CrossRef]

2. Finlayson-Pitts, F.C.; Pitts, J.N., Jr. (Eds.) Atmospheric Chemistry: Fundamentals and Experimental Techniques; John Wiley: Hoboken, NJ, USA, 1986.

3. Solomon, S.; Portmann, R.W.; Sanders, R.W.; Daniel, J.S.; Madsen, W.; Bartram, B.; Dutton, E.G. On the Role of Nitrogen Dioxide in the Absorption of Solar Radiation. J. Geophys. Res. 1999, 1041, 12047-12058. [CrossRef]

4. Crutzen, P.J. The Role of $\mathrm{NO}$ and $\mathrm{NO}_{2}$ in the Chemistry of the Troposphere and Stratosphere. Annu. Rev. Earth Planet. Sci. 1979, 7, 443-472. [CrossRef]

5. Sunyer, J.; Spix, C.; Quénel, P.; Ponce-de-León, A.; Pönka, A.; Barumandzadeh, T.; Touloumi, G.; Bacharova, L.; Wojtyniak, B.; Vonk, J.; et al. Urban Air Pollution and Emergency Admissions for Asthma in Four European Cities: the APHEA Project. Thorax 1997, 52, 760-765. [CrossRef] [PubMed]

6. Latza, U.; Gerdes, S.; Baur, X. Effects of Nitrogen Dioxide on Human Health: Systematic Review of Experimental and Epidemiological Studies Conducted between 2002 and 2006. Int. J. Hyg. Environ. Health 2009, 212, 271-287. [CrossRef] [PubMed]

7. Chen, R.; Samoli, E.; Wong, C.M.; Huang, W.; Wang, Z.; Chen, B.; Kan, H. CAPES Collaborative Group. Associations between Short-Term Exposure to Nitrogen Dioxide and Mortality in 17 Chinese Cities: the China Air Pollution and Health Effects Study (CAPES). Environ. Int. 2012, 45, 32-38. [CrossRef] [PubMed]

8. Ackermann-Liebrich, U.; Leuenberger, P.; Schwartz, J.; Schindler, C.; Monn, C.; Bolognini, G.; Bongard, J.P.; Brändli, O.; Domenighetti, G.; Elsasser, S.; et al. Lung Function and Long Term Exposure to Air Pollutants in Switzerland. Study on Air Pollution and Lung Diseases in Adults (SAPALDIA) Team. Am. J. Respir. Crit. Care Med. 1997, 155, 122-129. [CrossRef] [PubMed]

9. Schindler, C.; Ackermann-Liebrich, U.; Leuenberger, P.; Monn, C.; Rapp, R.; Bolognini, G.; Bongard, J.P.; Brändli, O.; Domenighetti, G.; Karrer, W.; et al. Associations between Lung Function and Estimated Average Exposure to $\mathrm{NO}_{2}$ in Eight Areas of Switzerland. The SAPALDIA Team. Swiss Study of Air Pollution and Lung Diseases in Adults. Epidemiology 1998, 9, 405-411. [CrossRef] [PubMed]

10. Panella, M.; Tommasini, V.; Binotti, M.; Palin, L.; Bona, G. Monitoring Nitrogen Dioxide and Its Effects on Asthmatic Patients: Two Different Strategies Compared. Environ. Monit. Assess. 2000, 63, 447-458. [CrossRef]

11. Smith, B.J.; Nitschke, M.; Pilotto, L.S.; Ruffin, R.E.; Pisaniello, D.L.; Willson, K.J. Health Effects of Daily Indoor Nitrogen Dioxide Exposure in People with Asthma. Eur. Respir. J. 2000, 16, 879-885. [CrossRef] [PubMed]

12. Gauderman, W.J.; McConnell, R.; Gilliland, F.; London, S.; Thomas, D.; Avol, E.; Vora, H.; Berhane, K.; Rappaport, E.B.; Lurmann, F.; et al. Association between Air Pollution and Lung Function Growth in Southern California Children. Am. J. Respir. Crit. Care Med. 2000, 162, 1383-1390. [CrossRef] [PubMed]

13. Gauderman, W.J.; Gilliland, G.F.; Vora, H.; Avol, E.; Stram, D.; McConnell, R.; Thomas, D.; Lurmann, F.; Margolis, H.G.; Rappaport, E.B.; et al. Association between Air Pollution and Lung Function Growth in Southern California Children: Results from a Second Cohort. Am. J. Respir. Crit. Care Med. 2002, 166, 76-84. [CrossRef] [PubMed]

14. Stieb, D.M.; Judek, S.; Burnett, R.T. Meta-Analysis of Time-Series Studies of Air Pollution and Mortality: Update in Relation to the Use of Generalized Additive Models. J. Air Waste Manag. Assoc. 2003, 53, 258-261. [CrossRef] [PubMed]

15. Burnett, R.T.; Stieb, D.; Brook, J.R.; Cakmak, S.; Dales, R.; Raizenne, M.; Vincent, R.; Dann, T. The Short-Term Effects of Nitrogen Dioxide on Mortality in Canadian Cities. Arch. Environ. Health 2004, 59, 228-237. [CrossRef] [PubMed]

16. Samoli, E.; Aga, E.; Touloumi, G.; Nisiotis, K.; Forsberg, B.; Lefranc, A.; Pekkanen, J.; Wojtyniak, B.; Schindler, C.; Niciu, E.; et al. Short Term Effects of Nitrogen Dioxide and Mortality: An Analysis within the APHEA Project. Eur. Respir. J. 2006, 27, 1129-1137. [CrossRef] [PubMed]

17. Schaap, M.; Müller, K.; ten Brink, H.M. Constructing the European Aerosol Nitrate Concentration Field from Quality Analysed Data. Atmos. Environ. 2002, 36, 1323-1335. [CrossRef] 
18. Tørseth, K.; Aas, W.; Breivik, K.; Fjæraa, A.M.; Fiebig, M.; Hjellbrekke, A.G.; Lund Myhre, C.; Solberg, S.; Yttri, K.E. Introduction to the European Monitoring and Evaluation Programme (EMEP) and Observed Atmospheric Composition Change During 1972-2009. Atmos. Chem. Phys. 2012, 12, 5447-5481. [CrossRef]

19. Zhou, Y.; Brunner, D.; Hueglin, C.; Henne, S.; Staehelin, J. Changes in OMI Tropospheric $\mathrm{NO}_{2}$ Columns over Europe from 2004 to 2009 and the Influence of Meteorological Variability. Atmos. Environ. 2012, 46, 482-495. [CrossRef]

20. Castellanos, P.; Boersma, K.F. Reductions in Nitrogen Oxides over Europe Driven by Environmental Policy and Economic Recession. Sci. Rep. 2012, 2, 265. [CrossRef] [PubMed]

21. Hilboll, A.; Richter, A.; Burrows, J.P. Long-Term Changes of Tropospheric $\mathrm{NO}_{2}$ over Megacities Derived from Multiple Satellite Instruments. Atmos. Chem. Phys. 2013, 13, 4145-4169. [CrossRef]

22. Curier, R.L.; Kranenburg, R.; Segers, A.J.S.; Timmermans, R.M.A.; Schaap, M. Synergistic Use of OMI $\mathrm{NO}_{2}$ Tropospheric Columns and LOTOS-EUROS to Evaluate the NOx Emission Trends across Europe. Remote Sens. Environ. 2014, 149, 58-69. [CrossRef]

23. Burrows, J.P.; Weber, M.; Buchwitz, M.; Rozanov, V.; Ladstätter-Weißenmayer, A.; Richter, A.; DeBeek, R.; Hoogen, R.; Bramstedt, K.; Eichmann, K.; et al. The Global Ozone Monitoring Experiment (GOME): Mission Concept and First Scientific Results. J. Atmos. Sci. 1999, 56, 151-175. [CrossRef]

24. Bovensmann, H.; Burrows, J.P.; Buchwitz, M.; Frerick, J.; Noël, S.; Rozanov, V.V.; Chance, K.V.; Goede, A.P.H. SCIAMACHY: Mission Objectives and Measurement Modes. J. Atmos. Sci. 1999, 56, 127-150. [CrossRef]

25. Levelt, P.F.; Hilsenrath, E.; Leppelmeier, G.W.; van den Oord, G.H.J.; Bhartia, P.K.; Tamminen, J.; de Haan, J.F.; Veefkind, J.P. Science Objectives of the Ozone Monitoring Instrument. IEEE Trans. Geosci. Remote Sens. 2006, 44, 1199-1208. [CrossRef]

26. Levelt, P.F.; van den Oord, G.H.J.; Dobber, M.R.; Malkki, A.; Visser, H.; de Vries, J.; Stammes, P.; Lundell, J.O.V.; Saari, H. The Ozone Monitoring Instrument. IEEE Trans. Geosci. Remote Sens. 2006, 44, 1093-1101. [CrossRef]

27. Callies, J.; Corpaccioli, E.; Eisinger, M.; Hahne, A.; Lefebvre, A. GOME-2, Metop's Second Generation Sensor for Operational Ozone Monitoring. ESA Bull. 2000, 102, 28-36.

28. Richter, A.; Burrows, J.P. Retrieval of Tropospheric $\mathrm{NO}_{2}$ from GOME Measurements. Adv. Space Res. 2002, 29, 1673-1683. [CrossRef]

29. Martin, R.V.; Chance, K.; Jacob, D.J.; Kurosu, T.P.; Spurr, R.J.D.; Bucsela, E.; Gleason, J.F.; Palmer, P.I.; Bey, I.; Fiore, A.M.; et al. An Improved Retrieval of Tropospheric Nitrogen Dioxide from GOME. J. Geophys. Res. 2002, 107, 4437. [CrossRef]

30. Boersma, K.F.; Eskes, H.J.; Brinksma, E.J. Error Analysis for Tropospheric $\mathrm{NO}_{2}$ Retrieval from Space. J. Geophys. Res. 2004, 109, D04311. [CrossRef]

31. Boersma, K.F.; Eskes, H.J.; Veefkind, J.P.; Brinksma, E.J.; van der A, R.J.; Sneep, M.; van den Oord, G.H.J.; Levelt, P.; Stammes, P.; Gleason, J.F.; et al. Near-Real Time Retrieval of Tropospheric $\mathrm{NO}_{2}$ from OMI. Atmos. Chem. Phys. 2007, 7, 2103-2118. [CrossRef]

32. Boersma, K.F.; Bucsela, E.J.; Brinksma, E.J.; Gleason, J.F. $\mathrm{NO}_{2}$. In OMI Algorithm Theoretical Basis Document, OMI Trace Gas Algorithms; ATB-OMI-04, Version 2.0; Chance, K., Ed.; NASA Distributed Active Archive Centers: Greenbelt, MD, USA, 2002; Volume 4.

33. Bucsela, E.J.; Celarier, E.A.; Wenig, M.O.; Gleason, J.F.; Veefkind, J.P.; Boersma, K.F.; Brinksma, E.J. Algorithm for $\mathrm{NO}_{2}$ Vertical Column Retrieval from the Ozone Monitoring Instrument. IEEE Trans. Geosci. Remote Sens. 2006, 44, 1245-1258. [CrossRef]

34. Celarier, E.A.; Brinksma, E.J.; Gleason, J.F.; Veefkind, J.P.; Cede, A.; Herman, J.R.; Ionov, D.; Goutail, F.; Pommereau, J.; Lambert, J.; et al. Validation of Ozone Monitoring Instrument Nitrogen Dioxide Columns. J. Geophys. Res. 2008, 113, D15S15. [CrossRef]

35. Platt, U. Differential Optical Absorption Spectroscopy (DOAS). In Air Monitoring by Spectroscopic Techniques; Sigrist, M., Ed.; John Wiley: Hoboken, NJ, USA, 1994; pp. 27-84.

36. Martin, R.V.; Jacob, D.J.; Chance, K.; Kurosu, T.P.; Perner, P.I.; Evans, M.J. Global Inventory of Nitrogen Oxide Emission Constrained by Space-Based Observations of $\mathrm{NO}_{2}$ Columns. J. Geophys. Res. 2003, 108, 4537. [CrossRef]

37. Hong, H.; Lee, H.; Kim, J.; Jeong, U.; Ryu, J.; Lee, D.S. Investigation of Simultaneous Effects of Aerosol Properties and Aerosol Peak Height on the Air Mass Factors for Space-Borne $\mathrm{NO}_{2}$ Retrievals. Remote Sens. 2017, 9, 208. [CrossRef] 
38. Dobber, M.; Kleipool, Q.; Dirksen, R.; Levelt, P.; Jaross, G.; Taylor, S.; Kelly, T.; Flynn, L.; Leppelmeier, G.; Rozemeijer, N. Validation of Ozone Monitoring Instrument Level 1b Data Products. J. Geophys. Res. 2008, 113, D15S06. [CrossRef]

39. Byun, D.; Schere, K. Review of the governing equations, computation algorithms, and other components of the Models-3 Community Multiscale Air Quality (CMAQ) modeling system. Appl. Mech. Rev. 2006, 59, 51-77. [CrossRef]

40. Byun, D.W.; Ching, J. Science Algorithms of the EPA Models-3 Community Multi-Scale Air Quality (CMAQ) Modeling System; NERL: Research Triangle Park, NC, USA, 1999; p. 425.

41. Sarwar, G.; Luecken, D.; Yarwood, G.; Whitten, G.; Carter, W. Impact of an Updated Carbon Bond Mechanism on Predictions from the CMAQ Modeling System: Preliminary Assessment. J. Appl. Meteorol. Climatol. 2008, 47, 3-14. [CrossRef]

42. Zhang, M.; Uno, I.; Sugata, S.; Wang, Z.; Byun, D.; Akimoto, H. Numerical Study of Boundary Layer Ozone Transport and Photochemical Production in East Asia in the Wintertime. Geophys. Res. Lett. 2002, 29. [CrossRef]

43. Zhang, M. Large-Scale Structure of Trace Gas and Aerosol Distributions over the Western Pacific Ocean During the Transport and Chemical Evolution Over the Pacific (TRACE-P) Experiment. J. Geophys. Res. 2003, 108, 8820. [CrossRef]

44. Zhang, M.G.; Uno, I.; Yoshida, Y.; Xu, Y.; Wang, Z.; Akimoto, H.; Bates, T.; Quinn, T.; Bandy, A.; Blomquist, B. Transport and Transformation of Sulfur Compounds over East Asia during the TRACE-P and ACE-Asia Campaigns. Atmos. Environ. 2004, 38, 6947-6959. [CrossRef]

45. Zhang, M.G. Modeling of Organic Carbon Aerosol Distributions over East Asia in the Springtime. China Part. 2004, 2, 192-195. [CrossRef]

46. Lu, Z.; Streets, D.G.; Zhang, Q.; Wang, S.; Carmichael, G.R.; Cheng, Y.F.; Wei, C.; Chin, M.; Diehl, T.; Tan, Q. Sulfur dioxide emissions in China and sulfur trends in East Asia since. Atmos. Chem. Phys. 2000, 10, 6311-6331. [CrossRef]

47. Lu, Z.; Zhang, Q.; Streets, D.G. Sulfur dioxide and primary carbonaceous aerosol emissions in China and India, 1996-2010. Atmos. Chem. Phys. 2011, 11, 9839-9864. [CrossRef]

48. Lei, Y.; Zhang, Q.; He, K.; Streets, D. Primary anthropogenic aerosol emission trends for China, 1990-2005. Atmos. Chem. Phys. 2011, 11, 931-954. [CrossRef]

49. Zhang, Q.; Streets, D.; Carmichael, G.; He, K.; Huo, H.; Kannari, A.; He, K.; Huo, H.; Kannari, A.; Klimont, Z.; et al. Asian emissions in 2006 for the NASA INTEX-B mission. Atmos. Chem. Phys. 2009, 9, 5131-5153. [CrossRef]

50. Han, X.; Ge, C.; Tao, J.; Zhang, M.; Zhang, R. Air quality modeling for a strong dust event in East Asia in March 2010. Aerosol Air Qual. Res. 2012, 12, 615-628. [CrossRef]

51. Han, X.; Zhang, M.; Tao, J.; Wang, L.; Gao, J.; Wang, S.; Chai, F. Modeling aerosol impacts on atmospheric visibility in Beijing with RAMS-CMAQ. Atmos. Environ. 2013, 72, 177-191. [CrossRef]

52. Han, X.; Zhang, M.; Gao, J.; Wang, S.; Chai, F. Modeling analysis of the seasonal characteristics of haze formation in Beijing. Atmos. Chem. Phys. 2014, 14, 10231-10248. [CrossRef]

53. Han, X.; Zhang, M.; Zhu, L.; Skorokhod, A. Assessment of the impact of emissions reductions on air quality over North China Plain. Atmos. Pollut. Res. 2016, 7, 249-259. [CrossRef]

54. Bucsela, E.J.; Perring, A.E.; Cohen, R.C.; Boersma, K.F.; Celarier, E.A.; Gleason, J.F.; Wenig, M.O.; Bertram, T.H.; Wooldridge, P.J.; Dirksen, R.; et al. Comparison of Tropospheric $\mathrm{NO}_{2}$ In Situ Aircraft Measurements with near-Real-Time and Standard Product Data from the Ozone Monitoring Instrument. J. Geophys. Res. 2008, 113, D16S31. [CrossRef]

55. Leue, C.; Wenig, M.; Wagner, T.; Klimm, O.; Platt, U.; Jähne, B. Quantitative Analysis of $\mathrm{NO}_{2}$ Emissions from Global Ozone Monitoring Experiment Satellite Image Sequences. J. Geophys. Res. 2001, 106, 5493-5505. [CrossRef]

56. Martin, R.V.; Sioris, C.E.; Chance, K.; Ryerson, T.B.; Bertram, T.H.; Wooldridge, P.J.; Cohen, R.C.; Neuman, J.A.; Swanson, A.; Flocke, F.M. Evaluation of Space-Based Constraints on Global Nitrogen Oxide Emissions with Regional Aircraft Measurements over and Downwind of Eastern North America. J. Geophys. Res. 2006, 111. [CrossRef] 
57. Jaeglé, L.; Steinberger, L.; Martin, R.V.; Chance, K. Global Partitioning of NOx Sources Using Satellite Observations: Relative Roles of Fossil Fuel Combustion, Biomass Burning and Soil Emissions. Faraday Discuss. 2005, 130, 407-423. [CrossRef] [PubMed]

58. Zhang, Q.; Streets, D.G.; He, K.; Wang, Y.; Richter, A.; Burrows, J.P.; Uno, I.; Jang, C.J.; Chen, D.; Yao, Z.; et al. NOx Emission Trends for China, 1995-2004, The View from the Ground and the View from Space. J. Geophys. Res. 2007, 112, D22306. [CrossRef]

59. Schaap, M.; Kranenburg, R.; Curier, L.; Jozwicka, M.; Dammers, E.; Timmermans, R. Assessing the Sensitivity of the OMI-NO $\mathrm{NO}_{2}$ Product to Emission Changes across Europe. Remote Sens. 2013, 5, 4187-4208. [CrossRef]

60. Lamsal, L.N.; Martin, R.V.; van Donkelaar, A.; Steinbacher, M.; Celarier, E.A.; Bucsela, E.; Dunlea, E.; Pinto, J.P.; Lamsal, C. Ground-level nitrogen dioxide concentrations inferred from the satellite-borne Ozone Monitoring Instrument. J. Geophys. Res. 2008, 113. [CrossRef]

61. Lamsal, L.N.; Martin, R.V.; van Donkelaar, A.; Celarier, E.A.; Bucsela, E.J.; Boersma, K.F.; Dirksen, R.; Luo, C.; Wang, Y. Indirect validation of tropospheric nitrogen dioxide retrieved from the OMI satellite instrument: insight into the seasonal variation of nitrogen oxides at northern midlatitudes. J. Geophys. Res. 2010, 115. [CrossRef]

(C) 2017 by the authors. Licensee MDPI, Basel, Switzerland. This article is an open access article distributed under the terms and conditions of the Creative Commons Attribution (CC BY) license (http://creativecommons.org/licenses/by/4.0/). 